\title{
Bacteriological Quality of Commonly Dispensed Non-prescription Drugs (Tablets) Sold in Patent Medicine Stores
}

\section{Nwachukwu 0 Ndubuisi ${ }^{1 *}$, Ezeagwula Divine ${ }^{1}$, Onyeagba A Reginald ${ }^{1}$, Unegbu N Valentine ${ }^{2}$ and Owanta I Julie ${ }^{1}$}

${ }^{1}$ Department of Microbiology, Abia State University, Abia State, Nigeria

${ }^{2}$ Department of Biology, Spiritan University, Abia State, Nigeria

*Corresponding Author: Nwachukwu O Ndubuisi, Department of Microbiology, Abia State University, Abia State, Nigeria.
Received: December 16, 2021

Published: January 13, 2022

(C) All rights are reserved by Nwachukwu 0

Ndubuisi., et al.

\begin{abstract}
Commonly consumed nonprescription oral dosage forms (tables) dispensed from Patent Medicine Stores are subject to unrestricted handling and potential contamination by microorganisms. We determined the bacteriological quality of tablets sold from patent medicine stores in Umuahia, Nigeria. A total of 113 items of 24 registered tablet brands were purchased. They were investigated for total bacterial count and presence of specified microorganisms using standard microbiological methods. Out of 113 items, $84(74.3 \%)$ tablets were free of microbial contamination while $14(12.4 \%)$ had bacterial counts $<10^{2} \mathrm{cfu} / \mathrm{ml}$. Only $2(1.8 \%)$ tablets exceeded the specified bacterial limit of $>2 \times 10^{3} \mathrm{cfu} / \mathrm{ml}$. None of the blister-packed tablets had bacterial growth on them. All the tablets dispensed ("counted") from large containers were contaminated by aerobic bacteria. The commonly encountered bacterial contaminants were Staphylococcus aureus and Bacillus species. Folic acid and Magnesium trisilicate were the most contaminated tablets. The tablets in blister packs were of excellent bacteriological quality.
\end{abstract}

Keywords: Bacteriological Quality; Patent Medicine Stores; Commonly Dispensed; Non Prescription Tablets

\section{Introduction}

Medicines are an essential part of human life and the safety of medicine is of utmost importance in providing pharmaceutical healthcare needs of patients [1].

Non prescription drugs available in tablet dosage forms are subject to unrestricted handling and are therefore, potentially susceptible to post-production contamination by microorganisms. Analgesics and vitamin products are among the most commonly available non-prescription drugs and are therefore subject to unrestricted post-production handling [2].

Most of the raw materials for pharmaceutical products support some form of microbial growth due to their nutritive properties and moisture content. Hence, dry tablets that are prepared with these raw materials are capable of undergoing some form of microbial spoilage or degradation $[1,3]$.
Patent medicine stores (PMS) are highly patronized in Nigeria and other developing countries because of low price of drugs, easy accessibility and low level of literacy of the populace [3]. These patient medicine stores are manned by quacks, who have no formal training in pharmacy.

The common practice of patent medicine stores, pharmacies, and retail pharmacies repackaging and dispensing bulk products into smaller dosage units increase product handling and the risk of microbial contamination from handlers and the environment [4]. Where dispensing hygiene is not good, in-use contamination can be gross [4].

The more serious problems of microbial contamination of tablets is where there are no obvious signs of spoilage and many cases of medicament related infections are probably not recognized or reported $[5,6]$. 
Oral dosage forms including tablets, although not required by most Pharmacopeia to be sterile, are nonetheless required to pass tests for the absence of certain specified microorganisms (Escherichia coli, Salmonella sp, Pseudomonas aeruginosa, S. aureus and Candida albicans) and microbial bioburden tests [7].

There has been paucity of reports of contamination of tablets dispensed from patent medicine store in Nigeria. This could be due to underestimation of health hazards to which patients are exposed through consumption of such tablets.

We therefore sought to determine the bacteriological quality of tablets dispensed from patent Medicine Stores in Umuahia, Nigeria.

\section{Materials and Methods}

\section{Collection of tablet dosage forms}

Twenty four different brands of tablet dosage forms were randomly purchased from 6 Patent Medicine Stores in Umuahia town, Abia State, Nigeria. Preference was for formulations with high public demand such as paracetamol, Diclofenac salt, Vitamin preparation and Magnesium trisilicate. All purchased drugs were manufactured by companies registered in Nigeria and their drugs approved by National Agency for Food and Drug Administration and Control (NAFDAC) for each brand, 3 packet and/or 30 "counted" tablets were obtained. A total of 113 units were tested.

\section{Preparation of tablets dispersion}

The blister of each brands of Ibuprofen Paracetamol and Diclofenac salt were swabbed with $70 \% \mathrm{v} / \mathrm{v}$ ethanol before opening. Similarly, the outside surfaces of containers containing Folic acid, Ascorbic acid, Ferrous sulphate and Magnesium trisilicate were also swabbed.

Five (5) tablets each of Ibuprofen, Ferrou sulphate, folic acid, Ascorbic acid and Diclofenac salt were dispersed in $10 \mathrm{ml}$ sterile normal saline while 5 tablets each of paracetamol and Magnesium trisilicate were dispersed in $20 \mathrm{ml}$ sterile normal saline. In general, $1 \mathrm{~g}$ of each tablet was used Tablet dispersion was mixed in a Vortex mixer for 5minutes to dislodge possible microbial cells and allowed to stand for 30 minutes. A 1:10 sample dilution of each tablet was prepared using the supernatant of each preparation.

\section{Bacterial enumeration}

Bacterial enumeration tests were conducted according to the United States Pharmacopeia USP31 [8] using the spread on the dry surface of Plate Count Agar. Triplicates plates were done for each dilution. After incubation at $37^{\circ} \mathrm{C}$ for $24 \mathrm{~h}$, developed colonies from each plate were enumerated and the arithmetic mean count was used for calculating the viable count of the test sample in colony forming units unit / $\mathrm{ml}$ (cfu/ml).

\section{Isolation of specified microbial contaminants}

Tests for specified microbial contaminants were carried out according to the USP 31 [8] with some minor modifications. Aliquots from each diluted sample wassubcultured on Mannitol Salt agar, MacConkey agar and Salmonella-Shigella agar (Titan Biotechn Ltd, India) for the detection of $S$. aureus, Pseudomonas aeruginosa, E. coli and Salmonella sp respectively. After incubation at $37^{\circ} \mathrm{C}$ for $24 \mathrm{~h}$, the isolated colonies were Gram stained characterized and identified as previously described [9].

\section{Results}

Macroscopic examination of the different tablets indicates that they were neat, wholesome and unexpired.

Over $74 \%$ of the items tested were free from microbial contamination. Exactly $12.4 \%$ of the tablet dosage forms had bacterial counts of $2 \times 10^{2} \mathrm{cfu} / \mathrm{ml}$. Only $1.8 \%$ of the tablets had bacterial counts $>2 \times 10^{3} \mathrm{cfu} / \mathrm{ml}$ (Table 1 ). USP31 specifies an acceptance criterion of a total viable count of not more than $2 \times 10^{3} \mathrm{cfu} / \mathrm{g}$ or $\mathrm{ml}$ for non-aqueous preparations for oral use. It was therefore observed that only 2 tablets were found to exceed the specified bacterial limits.

\begin{tabular}{|c|c|c|c|c|c|c|}
\hline \multirow[t]{2}{*}{ Tablet } & \multirow[t]{2}{*}{$\begin{array}{c}\text { No of unit } \\
\text { tested }\end{array}$} & \multirow[t]{2}{*}{$\begin{array}{c}\text { No contamination } \\
\text { free }(\%)\end{array}$} & \multicolumn{4}{|c|}{$\begin{array}{l}\text { Level of bacterial contamination } \\
(\mathbf{c f u} / \mathrm{ml})\end{array}$} \\
\hline & & & $<1.0(\%)$ & $<200(\%)$ & $200-2000(\%)$ & $2000(\%)$ \\
\hline Ibuprofen & 12 & 12 & 0 & 0 & 0 & 0 \\
\hline Paracetamol & 12 & 11 & 1 & 0 & 0 & 0 \\
\hline Diclofenac salt & 9 & 9 & 0 & 0 & 0 & 0 \\
\hline Folic acid & 20 & 13 & 4 & 3 & 0 & 0 \\
\hline Ascorbic acid & 20 & 11 & 3 & 6 & 0 & 0 \\
\hline Ferrous sulphate & 20 & 16 & 0 & 4 & 0 & 0 \\
\hline Magnesium trisilicate & 20 & 12 & 4 & 1 & 1 & 2 \\
\hline Total & 113 & $84(74.3)$ & $12(10.6)$ & $14(12.4)$ & $1(0.9)$ & $2(1.8)$ \\
\hline
\end{tabular}

Table 1: Distribution of bacterial counts in different tablet dosage forms. 
Our results showed that none of the blister-packed tablets (Ibuprofen, Paracetamol and Diclofenac salt) had bacterial growth on them. However, all the tablets dispersed (counted) from large container (Folic acid, Ascorbic acid, Ferrous sulphate and Magnesium trisilicate) had growth of aerobic bacteria (Table 2). The bacteria isolated from the tablets includes Bacillus sp and S. aureus. Bacillus sp and $S$. aureus occurred simultaneously on Folic acid and Magnesium trisilictae while $S$. aureus was isolated from Ascorbic acid and Ferrous sulphate (Table 2). The results presented in table 2 showed that other USP 31 indicator pathogens, E. coli, Salmonella sp and Pseudomonas aeruginosa were not recovered from the tablet dosage forms.

\begin{tabular}{|l|c|c|}
\hline Brand & $\begin{array}{c}\text { No of units } \\
\text { studied }\end{array}$ & Bacteria isolated \\
\hline Ibuprofen & 12 & None \\
\hline Paracetamol & 12 & None \\
\hline Diclofenac salt & 9 & None \\
\hline Folic acid & 20 & Bacillus, S. aureus \\
\hline Ascorbic acid & 20 & S. aureus \\
\hline Ferrous sulphate & 20 & S. aureus \\
\hline Magnesium trisilicate & 20 & S. aureus, Bacillus sp \\
\hline
\end{tabular}

Table 2: Types of bacterial contaminants isolated from different tablet dosage forms.

\section{Discussion}

Microorganisms have been implicated in drug spoilage and the presence of certain microorganisms in nonsterile preparations may have the potential to reduce or even inactivate the therapeutic activity of the product $[1,4,10]$. Our findings have shown that $74.3 \%$ of the tablets tested were free from bacterial contaminants. Similar result was reported by Qasem., et al [7] in Jordan (72.7\%).

Only $12.4 \%$ of the tested tablets harboured bacteria in counts between $10^{2}$ and $<10^{3} \mathrm{cfu} / \mathrm{ml}$. This observation falls within acceptance limit of the United States Pharmacopeia 31, an indication that all tested tablets were in conformity with standards in relation to microbial counts. It is also in agreement with $10.6 \%$ obtained previously $[7,11]$. These workers reported that out of 80 tablets dosage forms, $10 \%$ were contaminated with bacteria in counts ranging between $10^{2}$ and $10^{3} \mathrm{cfu} / \mathrm{g}$.

All the tablet dosage forms were manufactured in Nigeria. This low microbial count indicates that the microbiological quality of these made-in-Nigeria products were adequate. It thus confirms the role played by the National Agency for Food and Drug Administration and Control (NAFDAC).

Microbial counts obtained from similar previous studies in $\mathrm{Ni}$ geria $[3,12,13]$ indicated higher contamination rates where it was observed that out of all the tested products, none failed to grow microorganisms. This is in contrast to our findings. The recent enforcement by NAFDAC on Patent Medicine Stores and better adherence to current Good Manufacturing Practices by Pharmaceutical Companies in Nigeria account for the excellent result we obtained.

Tablets constitute a large proportion of the medicines dispersed from patent medicine stores. In our study, the blister-packed tablets did not harbor any bacteria whereas tablets "counted" from large containers were contaminated by bacteria. Contamination of blister-packed tablets does not occur after the blistering process. In modern dispensaries, tablets are now presented blister packs [7].

Dispensing of tablets from large packs is a common practice in patent medicine stores in Nigeria. It has been observed that the presence of contaminants on these "counted" tablets could be attributed to poor handling during dispensing, and/or repackaging and poor personal hygiene $[4,14]$.

Bacillus sp and S. aureus were the major contaminants isolated from tablets counted to the patients. Similar result was obtained by previous studies conducted in Nigeria $[3,13]$ and Dares Salam, Tanzania [15].

Ascorbic acid and Magnesium trisilicate tablets were mostly contaminated by Bacillus sp and $S$. aureus was the only indicator pathogen isolated. The presence of $S$. aureus as a contaminant reflects contamination of processing unit and/or raw material. The organism being a normal flora of the body easily contaminate products during handling and processing by personnel [16].

Bacillus species, a spore-former, was also commonly isolated from counted tablets. This is consistent with previous studies where majority of microbial contaminants in nonsterile pharmaceuticals was Bacillus sp [13,17,18].

Bacillus sp are ubiquitous and considered harmless, though undesirable because of their spoilage potential. Their presence in products suggest poor environmental hygiene during processing [15]. 
Two brands of Magnesium trisilicate, manufactured by a company had microbial counts $>10^{3} \mathrm{cfu} / \mathrm{g}$. It showed that GMP was not observed in the company.

\section{Conclusion}

Commonly dispensed non-prescription tablet dosage forms sold in patent medicine stores in Umuahia, Nigeria, were of good bacteriological quality.

Blister-packed tablets were free of bacterial contaminants. Detected contaminants were due to poor handling during dispensing (counting) and/or repackaging. It is imperative therefore that all commonly dispensed, non-prescription tablet dosage forms be formulated in blister packets.

\section{Bibliography}

1. Agbo BE., et al. "Prevalence of contaminating microorganisms in anti-malarial drugs sold in Calabar, Cross River State, Nigeria”. International Journal of Pharmaceutical Sciences and Research 7.10 (2016): 4272-4277.

2. Obuekwe CO., et al. "Surface Microbial contamination in some commonly available tablet dosage forms". Medical Principles and Practice 9 (2000): 290-293.

3. Obi CN and Nwannunu U. "Microbiological analyses of drugs tablets from selected outlets in Umuahia, Abia State, Nigeria". Research Journal of Pharmacology 4.2 (2010): 31-37.

4. Takon IA and Eyong EU. "Assessment of microbial quality of selected drug samples dispensed at six primary health centres in Aba Metropolis, Abia State, Nigeria". British Journal of Pharmaceutical and Medical Research 3.5 (2018): 1296-1303.

5. Vu JR and Kuptec TC. "Quality Control microbial limits tests for non-sterile pharmaceuticals. Part 2". International Journal of Pharmaceutical Compounding 18.4 (2014): 305-310.

6. Rania SHE., et al. "Recovery and detection of microbial contaminants in some non-sterile pharmaceutical products". Archives of Clinical Microbiology 4.6 (2013): 1.

7. Qasem, MAS., et al. "Microbiological quality of blister-pack tablets in community pharmacies in Jordan". Tropical Journal of Pharmaceutical Research 13.2 (2014): 261-263.

8. United States Pharmacopeial Convention. The United States Pharmacopeia: USP 31: The National Formulary: NF 26 (2008).

9. Cowan ST and Steel KJ. "Manual for the identification of medical bacteria". $2^{\text {nd }}$ Ed. Cambridge. Cambridge University Press (1984).
10. The International Pharmacopoeia. $9^{\text {th }}$ Ed. Microbiological quality of non-sterile products recommended acceptance criteria for Pharmaceutical preparations (2019).

11. Gad, GFM., et al. "Microbial evaluation of some non-sterile pharmaceutical preparations commonly used in the Egyptian". Tropical Journal of Pharmaceutical Research 10 (2011): 437445.

12. Muhammed A., et al. "Incidence and effects of microorganisms on quality of some pharmaceutical mixtures in Zaria, Nigeria". Nigerian Journal of Pharmaceutical Research 8 (2009): 126134.

13. Akerele JO and Ukoh GC. "Aspects of microbial contamination of tablets dispensed in hospitals and community pharmacies in Benin City, Nigeria". Tropical Journal of Pharmaceutical Research 1 (2002): 23-28.

14. Itah AJ., et al. "Bacteriological quality of some pharmaceutical products marketed by drug vendor in Uyo, Nigeria". African Journal of Health Sciences 11 (2004): 128-133.

15. Mugoyela U and Mwambete KD. "Microbial contamination of non-sterile pharmaceuticals in public hospital settings". Therapeutics and Clinical Risk Management 6 (2010): 443-448.

16. Obuekwe IF and Obuekwe CO. "Microbial contamination of pharmaceutical products in a tropical environment". Pakistan Journal of Scientific and Industrial Research 45 (2002): 340344.

17. Al-Charrach AH. "Frequency and antimicrobial resistance of bacteria isolated from oral and topical medicaments from Hilla, Iraq". Journal of Infection in Developing Countries 6 (2012): 489-494.

18. Mwambete SA. "Microbiological quality and preservative capacity of commonly available cosmetics in Dares Salaam, Tanzania". East and Central African Journal of Pharmaceutical Sciences 13 (2010): 3-11.

\section{Assets from publication with us}

- Prompt Acknowledgement after receiving the article

- Thorough Double blinded peer review

- Rapid Publication

- Issue of Publication Certificate

- High visibility of your Published work

Website: www.actascientific.com/

Submit Article: www.actascientific.com/submission.php Email us: editor@actascientific.com

Contact us: +919182824667 